\title{
Formulation and Evaluation of Polyherbal Oil
}

\author{
Neha N. Jagatap \\ Department of Pharmaceutics, Rajarambapu College of Pharmacy, Kasegaon, Maharashtra, India
}

\begin{abstract}
Article Info

Volume 8, Issue 4

Page Number : 690-697

Publication Issue

July-August-2021

Article History

Accepted : 25 Aug 2021

Published : 30 Aug 2021

The aim of present study involves preparation of polyherbal hair oil using plant materials. The prepared polyherbal hair oil evaluated different parameters within the acceptable limits. Such as phytochemical screening, organoleptic characterization, specific gravity, $\mathrm{pH}$, viscosity, acid value, saponification value, refractive index, and also stability study. Antimicrobial assay of the polyherbal hair oil was studied by the zone inhibition method. And these helps reduces dandruffs and scalp of hairs. And to provide nutrition's of hairs. The antioxidant activity of the oil was studied by DPPH radical scavenging activity. The primary skin irritation test is carried out. Hence, these polyherbal hair oil increases hair growth, reduces hair loss, providing protection against dandruff. Now-a-days increasing demand of herbal formulation than synthetic formulation. They have better safety and also fewer side effects. Polyherbal hair oil using various fresh leaves of Hibiscus Rosa Sinesis, Aloe Barbadensis leaf, curry leaves, amla, shikekai. These formulations coconut oil as the base. Hair care products used both hair tonic as well as hair grooming aids.
\end{abstract}

Keywords: polyherbal hair oil, antioxidant activity, antidandruff assay, herbs.

\section{INTRODUCTION}

Hair is one of the vital parts of our body and it influences the overall appearance of person. Hair is a protein filament that grows from follicles found in the dermis. Hair is one of the most important of our body that improves the overall appearance of person.(5)

The hair fall, dandruffs, split ends, gray hair are the major problem associated with hair. Hair loss is distressing condition for an increasing number of men and women. Hair loss is or alopecia, is a common patient problems/complaint. And a sopurce of significant psychological and physical distress. To overcome this problems, we use lots of hair care products use.(6)

In traditional Indian system of medicine many plants and herbal formulations are reported for hair growth promotion as well as improvement of quality of hair. Herbal care products are defined as those formulation which are used for cleansing, modifying the texture of 
hair, changing of colour, giving life to stressed hair and providing nourishment of the hair.(4)

Hair oils are the hair care formulations applied for treatment of hair disorders such as baldness, aggression of hair discoloring of hair, hair falling, dryness of hair. Herbal hair oils are formulated with herbal extracts in oil base (8)

In our study, we have formulated herbal hair oils from Hibiscus Rosasinesis, Murraya koenigii, Aloe barbadensis, Phyllanthus embilica, Acacia concinna, Coconut oil used for the best medicine of hair growth.

\section{A. Hibiscus Rosasinesis}

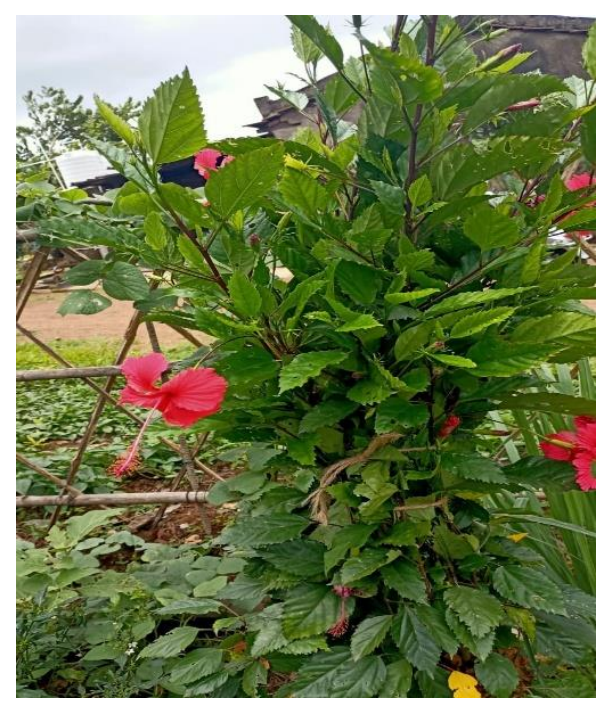

Figure1. Hibiscus Rosasinesis

Biological source-dried leaves of hibiscus Rosa sinesis. Family- Malvaceae.

Uses - Nourishes and thickens hair. emollient, brain tonic, growth of hair, blackening of hair, Luster of hair ,laxative, skin diseases, menorrhagia, treatment of bronchial catarrh, antiscorbutic, depurative.

Plant part used-Leaf (1)

\section{B. Curry Leaves}

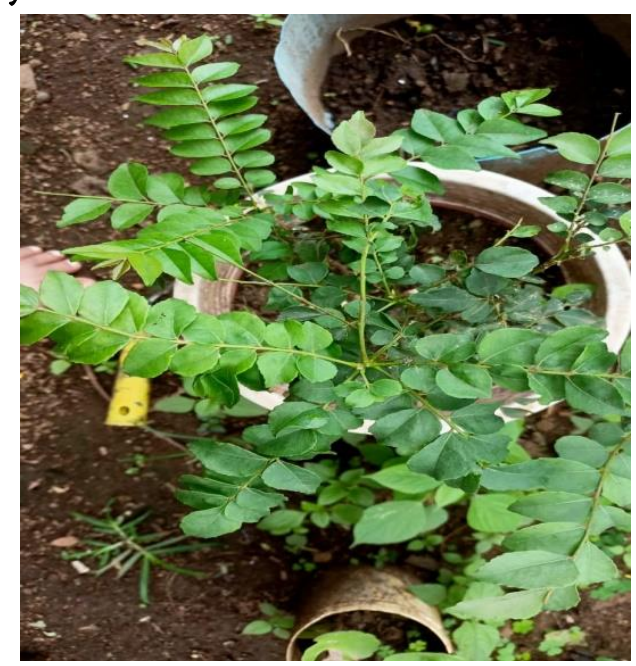

Figure 2. Curry plant

\section{Biological Source}

The species name commemorates the botanist Johann König. The genus Murray commemorates Swedish physician and botanist Johann Andreas Murray who died in 1791 . Hence the botanical name of the curry leaves is Murraya koenigii.

\section{Family-Rutaceae}

Uses- Use prevents hair fall and premature graying of hair.

Plant part used- Leaf (10)

\section{Aloe Vera}

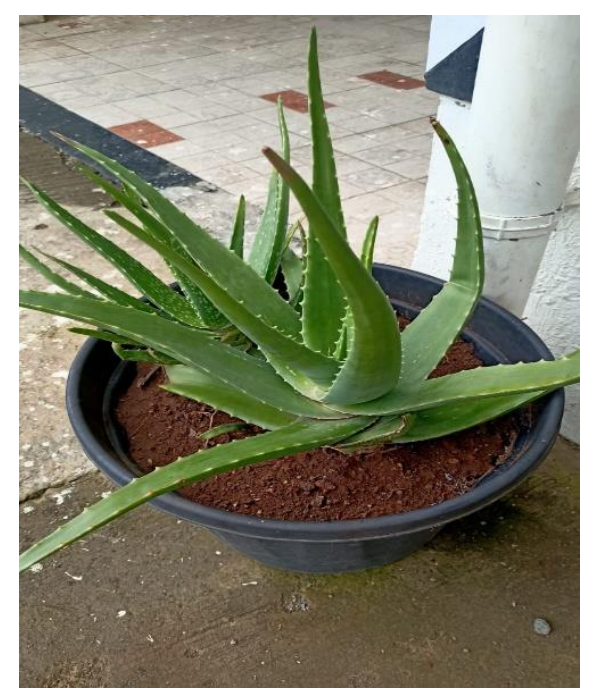

Figure 3. Aloe Vera 
Biological Source- Dried leaves of aloe barbadensis miller

\section{Family-Liliaceae}

Uses- Conditioner and moisturizing effect, remove dandruff, boost hair growth, nourishing the hair. Combination of aloe pulp and coconut oil are rich vitamins and minerals. These oil used as hair and scalp gives healthy, strong antidandruff free hair (antidandruff activity of the hair.)

Plant part used-whole plant. (2)

D. Amla

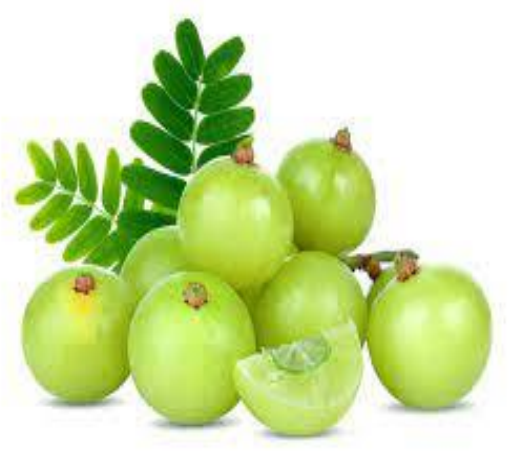

Figure 4. Amla

Biological Source- Dried fruits of phyllanthus embilica. Family Phyllanthaceae.

Uses- Hair conditioner ,treats scalp ailments ,promotes hair growth .amla is rich source of vitamin $\mathrm{c}$, tannins , and minerals such as phosphorus, iron ,calcium which provide nutrition to hair and also causes thick and dark hair.

Plant part used-Fruit (15)

\section{E. Shikekai}

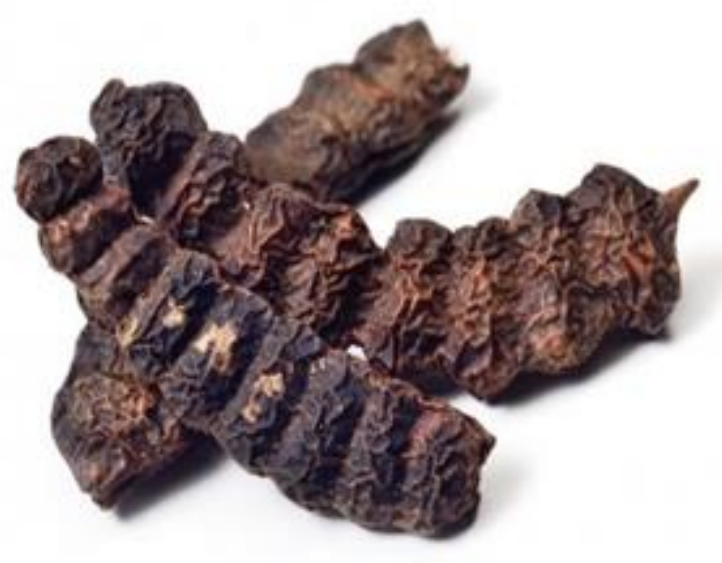

Figure 5. Shikekai

\section{Biological source-}

It consist of the fruits of the plant acacia concinna. Linn.

Family- Leguminosae

Uses- It is used as natural hair wash for sensitive scalps or to control dandruff. It promotes hair growth strengthen hair roots and lengthy beautiful hair .these is used for herbal hair oil.

Plant part used- Fruit (8)

\section{F. Coconut Oil}

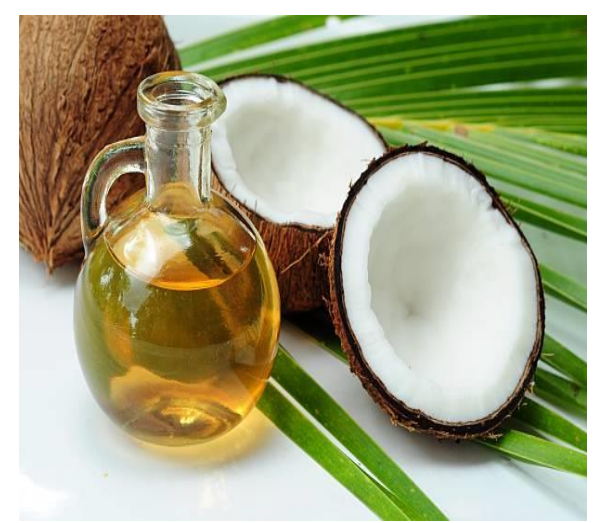

Figure 6. Coconut Oil

Biological source- Oil is derived from dried fruits of Cocus nucifera.

Family- Arecaceae

Uses- Nourishes of hair, moisturizing effect vehicle, stimulates hair growth by unclogging poers.

Plant part used-Fruit (6) 


\section{METHODS AND MATERIAL}

\section{Collection and authentication of plant materials}

The Polyherbal hair oil was prepared by collecting and using various plant materials these are, hibiscus rosasinesis leaf, curry leaf, aloe Vera leaf, amla, shikekai, coconut oil, are collected local region near Karad. Collected plants were identified by Dept. Of Botony, Yashwantrao Chavan College Of Science,Karad.The collected leaves were dried in the shade and then powder to coarse consistency and stored in an air tight container at room temperature.(13)

\section{Culture}

Clinical isolates of candida albiacans was procured from Rajarambapu College of pharmacy, kasegaon, Maharashtra for the in-vitro studies.

\section{Formulation of polyherbal hair oil}

All herbs of crude drugs are collected and dried under shade. Drying under shade will retain active constituents. Hence, shade drying is preferred over artificial drying. The dried crude drugs were made into course powder using mixer. Later on, all these coarsely powdered drugs are passed through mesh number80.this, obtained powders are blended together to get uniform mixture. Now coconut oil and aloe Vera pulp is added. These all dried powders of mixed well. Now contents were boiled $15 \mathrm{~min}$ and were filtrated through muslin cloth. To filtrate, coconut oil was added to make up volume. Finally, prepared polyherbal hair oil. And these are it was placed in amber colored bottle.(12)

Table 1. Formula for herbal oil

\begin{tabular}{|l|l|l|l|l|}
\hline Sr.no. & Ingredients & $\begin{array}{l}\text { F1 } \\
(\mathbf{2 \%})\end{array}$ & F2 (4\%) & $\begin{array}{l}\text { F3 } \\
(\mathbf{8 \% )}\end{array}$ \\
\hline 1 & $\begin{array}{l}\text { Hibiscus } \\
\text { rosasinesis }\end{array}$ & $6 \mathrm{gm}$ & $12 \mathrm{gm}$ & $16 \mathrm{gm}$ \\
\hline 2 & Curry leaf & $6 \mathrm{gm}$ & $12 \mathrm{gm}$ & $16 \mathrm{gm}$ \\
\hline
\end{tabular}

\begin{tabular}{|l|l|l|l|l|}
\hline 3 & Aloe Vera leaf & $6 \mathrm{gm}$ & $12 \mathrm{gm}$ & $16 \mathrm{gm}$ \\
\hline 4 & Amla & $6 \mathrm{mg}$ & $12 \mathrm{mg}$ & $16 \mathrm{mg}$ \\
\hline 5 & shikekai & $6 \mathrm{mg}$ & $12 \mathrm{mg}$ & $16 \mathrm{mg}$ \\
\hline 6 & Coconut oil & $50 \mathrm{ml}$ & $50 \mathrm{ml}$ & $50 \mathrm{ml}$ \\
\hline
\end{tabular}

\section{EVALUATION OF POLYHERBAL HAIR OIL}

\section{Phytochemical Screening of Polyherbal Hair Oil preparations}

The Prepared herbal oils were subjected to various qualitative chemical analysis for identification of various plant constituents like alkaloids, glycosides, flavonoids, tannins, phenols, steroids and saponins by using different techniques. $(13,14)$

\section{Physical Evaluation}

In the test, the herbal oil was observed for colour, odor, physical state, solubility, specific gravity, $\mathrm{PH}$, viscosity, refractive index, acid value and saponification value. were determined manually. (4)

\section{Primary Skin Irritation Test}

The prepared formulations are assessed for primary skin irritation test on our primary irritation test on our hand, little amount of F1, F2, F3, were applied on test site. The test site was observed for erythema and edema for 5 to 6 hrs. (8)

Antidandruff activity evaluation (anti-microbial activity) cup plate method

The polyherbal hair oil was carried out diffusin dependent antimicrobial activity by zone inhibition method. The plate was incubated at $37^{\circ} \mathrm{C}$ for 2 days. Zone of inhibition was measured.

\section{Antioxidant activity}

\section{DPPH radical scavenging test}

One $\mathrm{ml}$ of oil solutions $(20,30,40,50$ and $60 \mu \mathrm{g} / \mathrm{ml}$. in acetone) was added to one $\mathrm{ml}$ of $\mathrm{DPPH}$ solution $(0.2 \mathrm{Mm}$ in acetone). After a $30 \mathrm{~min}$ of reaction at room temperature, the absorbance of the was measured at $517 \mathrm{~nm}$. The antioxidant activity of the oil is measured against ascorbic acid as standard. (15) 


\section{Stability Studies}

Prepared polyherbal hair oil is observed for stability conditions. The polyherbal hair oil is observed for 1 , 2,3,4,5 and 6 months intervals. (2)

\section{RESULTS AND DISCUSSION}

Phytochemical screening of polyherbal hair oil preparations

Table 2. phytochemical evaluation of polyherbal hair oil

\begin{tabular}{|l|l|}
\hline Name of the Test & Results \\
\hline Alkaloids & -ve \\
\hline Flavonoids & $+\mathrm{ve}$ \\
\hline Steroids and Terpenoids & $+\mathrm{ve}$ \\
\hline Glycosides & $+\mathrm{ve}$ \\
\hline Tannins & $+\mathrm{ve}$ \\
\hline Saponins & -ve \\
\hline Phenols & $+\mathrm{ve}$ \\
\hline
\end{tabular}

\section{Physical Evaluation}

Table 3. organoleptic characrestics of polyherbal hair oil

\begin{tabular}{|l|l|l|l|}
\hline parameters & F1 & F2 & F3 \\
\hline Colour & $\begin{array}{l}\text { Greenish } \\
\text { brown }\end{array}$ & $\begin{array}{l}\text { Greenish } \\
\text { brown }\end{array}$ & $\begin{array}{l}\text { Greenish } \\
\text { brown }\end{array}$ \\
\hline odour & Pleasant & Pleasant & pleasant \\
\hline Physical state & $\begin{array}{l}\text { Liquid } \\
\text { with } \\
\text { greasy in } \\
\text { nature }\end{array}$ & $\begin{array}{l}\text { Liquid } \\
\text { with } \\
\text { greasy in } \\
\text { nature }\end{array}$ & $\begin{array}{l}\text { Liquid } \\
\text { with } \\
\text { greasy in } \\
\text { nature }\end{array}$ \\
\hline solubility & $\begin{array}{l}\text { Non-polar } \\
\text { solvents }\end{array}$ & $\begin{array}{l}\text { Non-polar } \\
\text { solvents }\end{array}$ & $\begin{array}{l}\text { Non-polar } \\
\text { solvents }\end{array}$ \\
\hline $\begin{array}{l}\text { Specific } \\
\text { gravity }\end{array}$ & 0.98 & 0.88 & 0.84 \\
\hline pH & 5.95 & 5.78 & 5.53 \\
\hline Viscosity & 0.0505 & 0.0525 & 0.0549 \\
\hline Acid value & 9.452 & 14.366 & 16.85 \\
\hline Saponification & 18.659 & 27.368 & 24.785 \\
\hline
\end{tabular}

\begin{tabular}{|l|l|l|l|}
\hline value & & & \\
\hline $\begin{array}{l}\text { Refractive } \\
\text { index }\end{array}$ & 1.5047 & 1.5837 & 1.7345 \\
\hline Skin irritation & $\begin{array}{l}\text { No } \\
\text { irritation }\end{array}$ & $\begin{array}{l}\text { No } \\
\text { irritation }\end{array}$ & $\begin{array}{l}\text { No } \\
\text { irritation }\end{array}$ \\
\hline
\end{tabular}

Antidandruff activity evaluation (anti-microbial activity) cup plate method

Antidandruff activity was carried out by measuring the zone of inhibition of different concentrations of polyherbal hair oil. all polyherbal hair oil showed good more activity as standard. Whereas F3 showed more activity against fluconazole shown in table 4 .

Table 4. zone of inhibition of polyherbal hair oil

\begin{tabular}{|c|c|c|c|c|c|}
\hline \multirow{2}{*}{$\begin{array}{l}\text { Microorganis } \\
\text { ms (candila } \\
\text { albiacans) }\end{array}$} & \multicolumn{5}{|c|}{ Zone of inhibition in $\mathrm{cms}$} \\
\hline & F1 & F2 & F3 & $\begin{array}{l}\text { Standar } \\
\mathrm{d} \\
\text { (Flucon } \\
\text { azole) }\end{array}$ & $\begin{array}{l}\text { Control } \\
\text { (Coconu } \\
\text { t oil) }\end{array}$ \\
\hline TRIL1(cm) & 1.3 & 1.3 & 1.5 & \multirow{4}{*}{$1 \mathrm{~cm}$} & \multirow{4}{*}{$0.9 \mathrm{~cm}$} \\
\hline TRIL2(cm) & 1.2 & 1.2 & 1.4 & & \\
\hline TRIL3(cm) & 1 & 1.3 & 1.5 & & \\
\hline AVG.(cm) & 1.1 & 1.17 & $\begin{array}{l}1.4 \\
7\end{array}$ & & \\
\hline
\end{tabular}

\section{Antioxidant activity}

\section{DPPH radical scavenging test}

Antioxidant activity was carried out in DPPH radical scavenging assay. Polyherbal hair oil concentrations three showed more scavenging activity as compared to other concentrations. Antioxidant activity of polyherbal hair oil was studied by DPPH method, by taking ascorbic acid as standard. And results shown in table 5, 6, 7 and figure.7, 8, 9 respectively. 
Table 5.absorbance and \% radical scavenging activity values of different concentrations of F1

\begin{tabular}{|l|l|l|}
\hline $\begin{array}{l}\text { Concentrati } \\
\text { ons } \\
(\mu \mathrm{l} / \mathrm{ml})\end{array}$ & Absorbance & $\begin{array}{l}\text { \% Radical } \\
\text { Scavenging } \\
\text { Activity }\end{array}$ \\
\hline 20 & 0.235 & $35.26 \%$ \\
\hline 30 & 0.341 & $47.66 \%$ \\
\hline 40 & 0.362 & $58.49 \%$ \\
\hline 50 & 0.414 & $56.79 \%$ \\
\hline 60 & 0.448 & $66.57 \%$ \\
\hline $\begin{array}{l}\text { Standard(Asc } \\
\text { orbic acid) }\end{array}$ & 0.06 & $88.79 \%$ \\
\hline
\end{tabular}

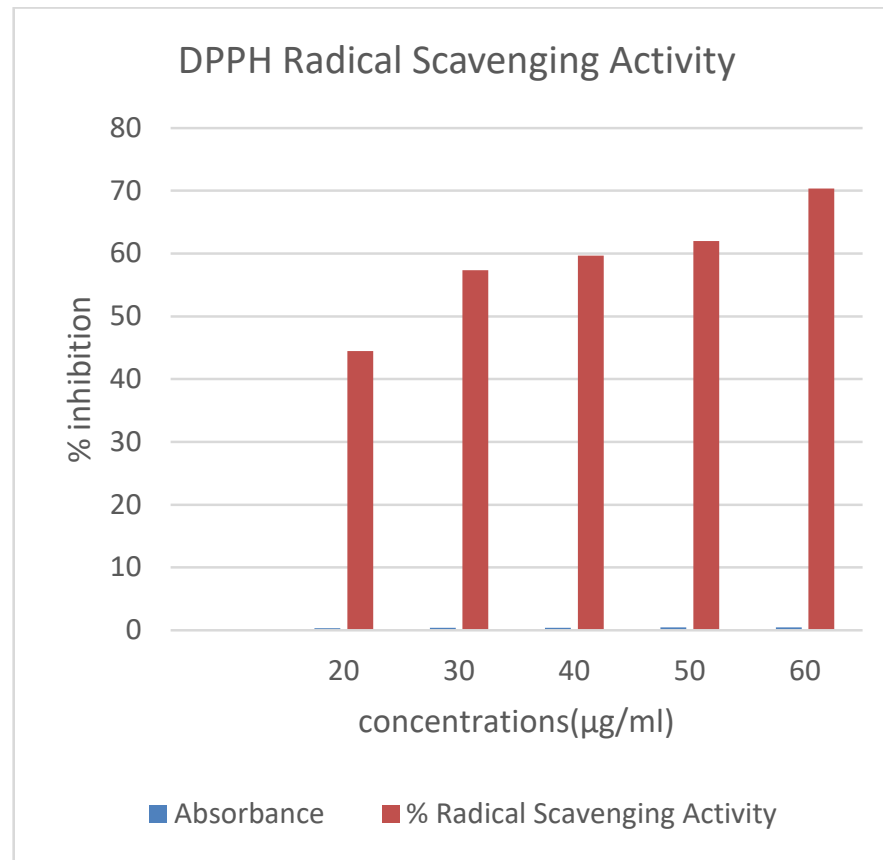

Figure 7. Effect of polyherbal hair oil 1- on DPPH Scavenging Activity

Table 6. absorbance and \% radical scavenging activity values of different concentrations of F2

\begin{tabular}{|l|l|l|}
\hline $\begin{array}{l}\text { Concentrations } \\
(\mu \mathrm{g} / \mathrm{ml})\end{array}$ & Absorbance & $\begin{array}{l}\text { \%Radical } \\
\text { Scavenging } \\
\text { Activity }\end{array}$ \\
\hline 20 & 0.272 & 38.87 \\
\hline
\end{tabular}

\begin{tabular}{|l|l|l|}
\hline 30 & 0.368 & 54.45 \\
\hline 40 & 0.384 & 56.88 \\
\hline 50 & 0.422 & 58.90 \\
\hline 60 & 0.468 & 69.22 \\
\hline $\begin{array}{l}\text { Standard } \\
\text { (Ascorbic Acid) }\end{array}$ & 0.06 & $88.79 \%$ \\
\hline
\end{tabular}

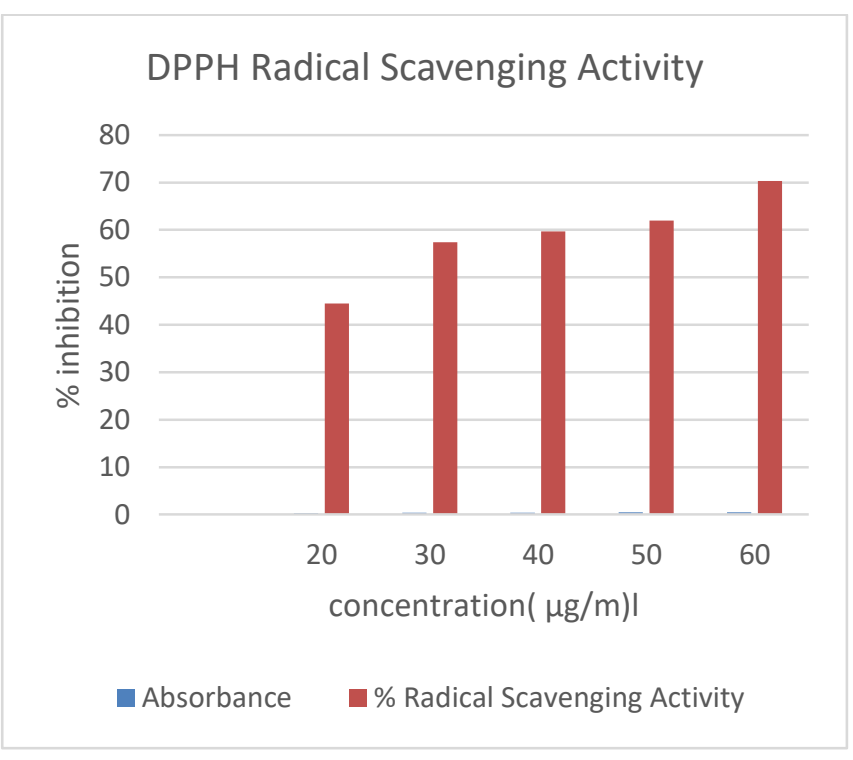

Figure. 8. effect of polyherbal hair oil 2-on DPPH Radical Scavenging Activity

Table 7. absorbance and \% radical scavenging activity values of different concentrations F3

\begin{tabular}{|l|l|l|}
\hline $\begin{array}{l}\text { Concentrations } \\
(\mu \mathrm{g} / \mathrm{ml})\end{array}$ & Absorbance & $\begin{array}{l}\text { \% Radical } \\
\text { Scavenging } \\
\text { Activity }\end{array}$ \\
\hline 20 & 0.327 & 44.48 \\
\hline 30 & 0.396 & 57.38 \\
\hline 40 & 0.419 & 59.64 \\
\hline 50 & 0.439 & 62.00 \\
\hline 60 & 0.485 & 70.33 \\
\hline $\begin{array}{l}\text { Standard } \\
\text { (Ascorbic } \\
\text { Acid })\end{array}$ & 0.06 & 88.79 \\
\hline
\end{tabular}




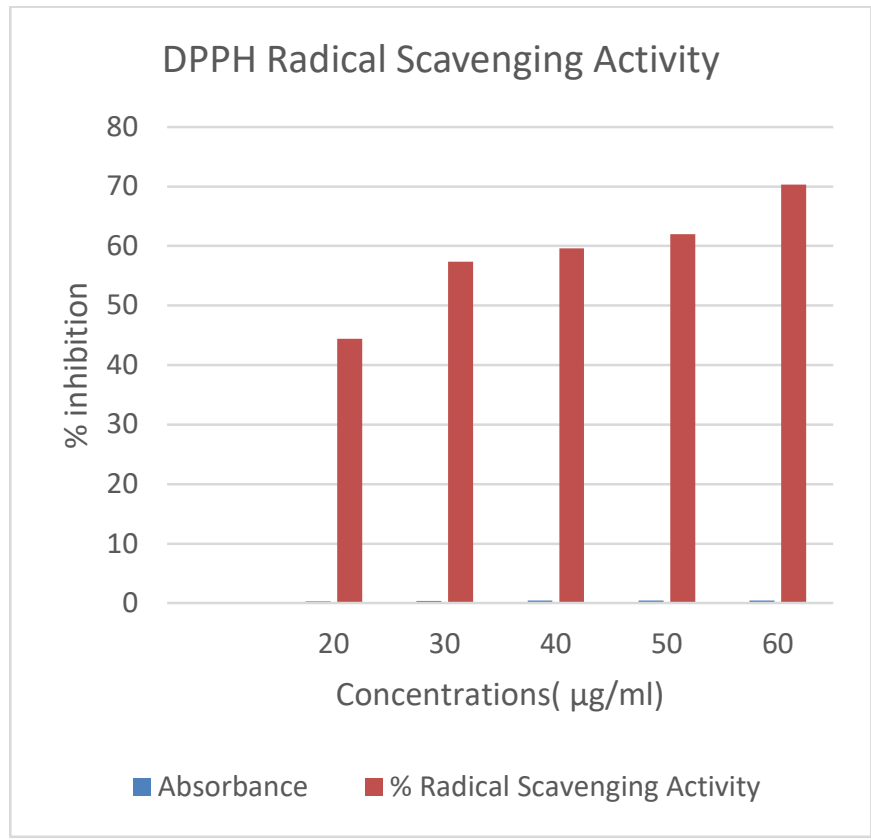

Figure 9. Effect of polyherbal hair oil 3- on DPPH Radical Scavenging Activity

\section{IV.CONCLUSION}

Polyherbal hair oil is one of the most well recognized hair treatments. Herbal formulations provides best mixture of vitamins, antioxidants, essential oils, and also provides nutrients of hair growth. These formulations maintaining good hair growth of hairs, stopping hair loss, reduces dandruff of hairs, also shining of hairs.

\section{ACKNOWLEDEMENT}

The authors are thankful to Rajarambapu College of pharmacy kasegaon. For their constant support and facilities provided during the study.

\section{REFERENCES}

[1]. Sunita verma. Hibiscus Rosa-sinesis multipurpose ornamental plant. International journal of research in pharmacology and pharmacotherapeutics.2016; 6(1):61-64.
[2]. Roji bista, arjun ghimire and sadikshya subedi. Phytochemicals and antioxidant activities of aloe Vera. Journal of nutritional sciences and healthy diet 2020; 1(1):25-36.

[3]. Kokate C.K, purohit A P and Gokhale S.B. In; Pharmacognosy, 19th Ed, nirali prakashan, pune, 2002.

[4]. Ramaya kuber, ch.lavanya, ch.nagaharitha, preeti, Rosa. Preparation and evaluation of polyherbal hair oil. Journal of drug delivery and therapeutics 2019; 9(1):68-73.

[5]. Usha kiran reddy, G.sindhu, Rajesh, Aruna, k.s.sandyarani. Preparation and evaluation of herbal hair oil.2017; 4(6):1540-1546.

[6]. Banerjee PS, Sharma M, Kumar RN. Preparation, evaluation and hair growth stimulating activity of herbal hair oil.J.Chem Pharm Res.2009; 1(1):261-267.

[7]. Ayyanar M, Lgnacimuthus, Medicinal plants used by tribal of tiruneveli hills, tamilnadu to great poisonous bites and skin diseases. Indian journal of traditional knowledge.2005; 4(3):229236.

[8]. Fatima grace $\mathrm{X}$, Rahul raj s, shanmughanathan s, chanmundeeshwari. Preparation and evaluation of polyherbal hair oil. International journal of pharmaceutical chemistry and analysis .2014; 1(1):2394-2797.

[9]. Ayurvedic pharmacopeia of India. Volume II, Vaidyagarathnavali; 2014.

[10]. S.Gejalakshmi, G.Pooja, B.A.Tanisha. Formulation and evaluation of polyherbal hair oil. Drug innovation today.2020; 13(1).

[11]. Indian Pharmacopeia 2007; volume I.

[12]. Yamani N, Sudha SS, Jyostna JJ, Pratyusha K, Pratyusha Kartheeka JA. Formulation and evaluation of polyherbal hair oil Pharmacogn phytochem .2018; 7:3254-6.

[13]. Dwidi S. Formulation and evaluation of herbal hair oil. Int J Chem Sci. 2012; 10:349-53.

[14]. Amol joshi and Pravin dyawarkonda. Formulation and evaluation of polyherbal hair 
oil. International journal of green pharmacy.2017; 11(1):135-139.

[15]. Suresh Kumar P, Sucheta S, Umamaheswari A, Sundarshana Deepa V, In Vitro and In vivo evaluation of anti-dandruff activity of formulated polyherbal hair oil. Journal of pharmacy research .2010; 3(12):2956-2958.

[16]. Habeeba Shaikh, Siddiqua Shaikh and Priya Rao. A Review on Indian traditional herb Murraya koenigii its nutritive and medicinal properties in human health management. 2020; 9(6):850-863.

\section{Cite this article as :}

Neha N. Jagatap, "Formulation and Evaluation of Polyherbal Oil", International Journal of Scientific Research in Science and Technology (IJSRST), Online ISSN : 2395-602X, Print ISSN : 2395-6011, Volume 8 Issue 4, pp. 690-697, July-August 2021. Available at doi : https://doi.org/10.32628/IJSRST2184103

Journal URL : https://ijsrst.com/IJSRST2184103 